\title{
$\beta$-Endorphin processing and cellular origins in rat spinal cord
}

\author{
Howard B. Gutstein, David M. Bronstein and Huda Akil \\ Department of Anesthesiology and Mental Health Research Institute, University of Michigan, Ann Arbor, MI (USA)
}

(Received 7 February 1992, revision received 24 June 1992, accepted 26 June 1992)

\begin{abstract}
Summary While enkephalin and dynorphin peptides have been well characterized in the spinal cord, the cellular localization of $\beta$-endorphin $(\beta \mathrm{E})$ and the processing of pro-opiomelanocortin (POMC) to $\beta \mathrm{E}$ and other non-opioid peptides in the cord have not been extensively investigated. Other investigators have characterized the various $\beta \mathrm{E}$ forms present in rat spinal cord regions. Previous studies have also suggested that spinal POMC content is entirely derived from supraspinal sources. However, high proportions of $\beta \mathrm{E}$ precursors present in spinal cord sieving profiles led us to suspect the presence of POMC cell bodies intrinsic to the cord. In this study, we performed thoracic spinal cord lesions on a group of animals and demonstrated the persistence of about one-third of control levels of $\beta \mathrm{E}$ immunoreactivity ( $\beta \mathrm{E}-\mathrm{IR}$ ) below the level of the lesions. We also characterized POMC processing in various regions of the spinal cord both before and after lesioning. These data suggested that there may be intrinsic POMC/endorphinergic neuronal systems in the spinal cord.
\end{abstract}

Key words: Pro-opiomelanocortin; $\beta$-Endorphin; Spinal cord; Peptide processing

\section{Introduction}

Pain research has increasingly focused on the role of the spinal cord in the modulation and processing of nociceptive inputs. Part of this attention has been focused on the possible role of opioid peptides, in particular enkephalin and dynorphin, in modulating nociceptive inputs from primary afferent fibers in the dorsal horn of the cord (Cruz and Basbaum 1985; Iadarola et al. 1988a,b). Enkephalin may provide an evanescent analgetic effect because of its rapid degradation after release (Frederickson et al. 1981; Holaday 1985). Dynorphin has been shown to modulate certain types of pain at kappa receptors. However, it has also been shown to have no analgetic effect and antagonistic non-opioid effects (Tung and Yaksh 1982; Walker et al. 1982a,b). In spite of the fact that $\beta$-endorphin $(\beta E)$ in its unacctylated, 31 amino acid form, is one of the most potent endogenous analgetic compounds (Bradbury et al. 1976; Deakin et al. 1980), little re-

Correspondence to: Howard B. Gutstein, M.D., Section of Pediatric Anesthesiology, C.S. Mott Children's Hospital (C-4139), Box 0800, Ann Arbor, MI, 48109-0800, USA. search has been done to determine whether this peptide is important in the control of nociception at the spinal level. $\beta \mathrm{E}$ has been shown to play important roles in stimulation-produced analgesia, stress-induced analgesia, and in supraspinal modulation of nociceptive input (Akil 1982). While immunohistochemical data (Tsou et al. 1986) first revealed the presence of $\beta \mathrm{E}$ immunoreactivity ( $\beta \mathrm{E}$-IR) in the cord, the potential involvment of this opioid in spinal pain processing could not be ascertained without a better appreciation of the origins and molecular forms of this immunoreactivity (IR). $\beta \mathrm{E}$ is differentially processed in regions of the CNS to opioid active, inactive, and antagonistic forms (Zakarian and Smyth 1979; Akil et al. 1981; Chretien et al. 1984; Hammonds et al. 1984). It is possible that each of these forms, or perhaps the relative ratios of these forms present at a synapse, could be important in the modulation of nociceptive information.

$\beta \mathrm{E}$ is derived from pro-opiomelanocortin (POMC), 1 of 3 known endogenous opioid peptide precursors. Its anatomic distribution in the CNS and pituitary appears to be more discrete than that of other endogenous opioids, cell bodies being localized to the anterior and intermediate lobes of the pituitary, the arcuate 
nucleus of the hypothalamus, and the nucleus tractus solitarius (NTS) in the medulla (Khachaturian et al. 1985). Post-translational processing of POMC has been well characterized in the pituitary, the arcuate nucleus, and the caudal medulla (Dores et al. 1986; Akil et al. 1988). POMC undergoes proteolytic cleavage to several biologically active end products, the most prominent of which are $\beta \mathrm{E}, \mathrm{ACTH}$, and $\alpha-\mathrm{MSH} . \beta \mathrm{E}_{1-31}$ is known to subsequently undergo $\mathrm{N}$-acetylation and $\mathrm{C}$-terminal proteolytic cleavage to $\beta \mathrm{E}_{1-27}$ and $\beta \mathrm{E}_{1-26}$ in a tissuespecific manner (Zakarian and Smyth 1982; Akil et al. 1984; Dores et al. 1986). Cleavage of $\beta \mathrm{E}_{1-31}$ to $\beta \mathrm{E}_{1-27}$ changes the compound from a strong opioid agonist to an opioid antagonist (Hammonds et al. 1984; Nicolas et al. 1984). $N$-acetylation of these compounds makes them opioid-inactive (Smyth et al. 1979; Deakin et al. 1980; Akil et al. 1981b). Thus, different patterns of POMC processing could result in peptide products that possess dramatically different pharmacologic, and possibly physiologic, properties.

For several years, it has been thought that all of the $\beta \mathrm{E}$ present in the spinal cord of adult rats was derived from cells of supraspinal origin (Khachaturian et al. 1985; Tsou et al. 1986). However, a developmental study by Haynes et al. (1982) showed that $\beta$ E-producing cells were present in the spinal cords of rat embryos, only to become undetectable by immunocytochemistry (ICC) after 28 days of postnatal life. In a subsequent study, $\beta E$-IR nerve fibers were seen coursing through the entire length of the spinal cord (Tsou et al. 1986). After thoracic spinal cord lesions were performed, these fibers completely disappeared below the level of the lesion. This suggested that all of the $\beta E-I R$ detected in the spinal cord was derived from supraspinal sources. However, preliminary molecular sieving profiles of spinal cord regions done in our lab (H. Akil, unpublished data) showed a level of POMC precursor products (i.e., POMC and $\beta-\mathrm{LPH}$, a biosynthetic intermediate) much higher than those observed in more rostral areas of the CNS. Since peptides tend to undergo more extensive processing as they are transported from the cell body to the nerve terminal, this observation suggested that there may be intrinsic endorphinergic neurons in the spinal cord. If all of the spinal $\beta \mathrm{E}$ was derived from supraspinal sources, one would expect to see a degree of peptide processing at least equivalent to that observed in the arcuate and NTS (i.e., nearly complete processing of POMC and $\beta$-LPH to $\beta \mathrm{E}_{1-31}, \beta \mathrm{E}_{1-27}$ and $\left.\beta \mathrm{E}_{1-26}\right)$. These somewhat contradictory pieces of data led us to suspect the existence of POMC-containing neurons intrinsic to the spinal cord that were undetectable by previously used experimental methods. Therefore, we carried out spinal cord lesion experiments and determined whether any POMC end products remained below the level of the lesion by using radioimmunoassay (RIA) coupled to gel chromatography, an approach which in our hands is significantly more sensitive than ICC (Akil et al. 1981a; Watson and Akil 1983). This approach allowed us to determine if any persistent $\beta \mathrm{E}$-IR was present in a biologically significant form. It also permitted comparison of the extent of $\beta \mathrm{E}$ processing in lesioned and unlesioned animals. If these processing patterns differed, the data would tend to support the existence of an unique intrinsic spinal endorphinergic system.

\section{Methods}

\section{Surgery and dissection}

Prior approval for all studies was obtained from the Universiy Committe on Use and Care of Animals. The ethical guidlines of the International Association for the Study of Pain (Zimmermann 1983) were followed throughout the experiments. Two groups of animals were studied in order to characterize POMC processing in the spinal cord and to determine whether spinal $\beta \mathrm{E}$ was derived exclusively from supraspinal sources. The 1st study involved 8 male SpragueDawley rats (250-300 g. Charles River, Portage, MI, USA), which were killed by decapitation. The spinal cords were immediately dissected free, divided into cervical, thoracic, lumbar, and sacral sections, and frozen on dry ice. Subsequently, RIAs for $\beta \mathrm{E}, N$-acetyl $\beta \mathrm{E}(N \mathrm{Ac} \beta \mathrm{E}), \mathrm{ACTH}$, and $\alpha$-MSH were performed on aliquots from each segment. The 2 nd study was performed to determine whether there was a POMC system intrinsic to the spinal cord. Eight male Sprague-Dawley rats were anesthetized with chloral hydrate and underwent complete excision of 2 upper thoracic segments of the spinal cord at the $T_{3}$ and $T_{4}$ level. Six rats underwent sham operation under chloral hydrate anesthesia, which consisted of removal of the spinous processes of the $T_{3}$ and $T_{4}$ vertebral bodies. Five unoperated rats were used as controls. The animals were allowed to recover from the surgery and then all rats were housed in individual, specially padded cages. Spinalized rats also underwent bladder expression 3 times a day and received prophylactic antibiotics (Kefzol $15 \mathrm{mg} / \mathrm{kg}$, i.p. daily). Three days after surgery, the animals were killed, lesions were verified in situ, and cords were immediately dissected, sectioned, and frozen on dry ice.

\section{RLAs}

Peptides were extracted by homogenizing samples for $30 \mathrm{sec}$ by polytron in acelone: $0.1 \mathrm{~N} \mathrm{HCl}(3: 1, \mathrm{w} / \mathrm{v})$ solution. Samples were then centrifuged, and supernatants collected and lyophilized overnight. The samples were then resuspended in $1 \%$ formic acid with $0.01 \%$ BSA. Aliquots of these samples were then taken, lyophilized, and resuspended in RIA buffer $(150 \mathrm{mM}$ sodium phosphate buffer with $1 \% \mathrm{NaCl}$ and $0.1 \% \mathrm{BSA}, \mathrm{pH} 8.2)$ for subsequent assay. All samples were quantitated relative to a standard curve run with each assay.

$\beta$-Endorphin RIA. The antiserum used for the $\beta \mathrm{E}$ assay (Brenda) was directed primarily against the midportion of $\beta E$ and was completely cross-reactive with POMC, $\beta$-LPH, $\beta E_{1-31}, N A c \beta E_{1-31}$, had $85 \%$ molar cross-reactivity with $\beta \mathrm{E}_{1-27}, \beta \mathrm{E}_{1-26}$ and their $N$ acetylated derivatives, and showed no cross-reactivity with other POMC-derived peptides such as $\beta \mathrm{E}_{1-16}, \beta \mathrm{E}_{1-17}$, des-tyrosine $\beta \mathrm{E}_{1-17}, \beta \mathrm{E}_{27-31}, \mathrm{ACTH}_{1-39}, \alpha \mathrm{MSH}$, or $\gamma \mathrm{MSH}$ (Cahill et al. 1983; Dores et al. 1986). In addition, it did not cross-react with peptides from other opioid precursors (i.e., Leu- or Met-enkephalin, dynorphin $\mathbf{A}$ or $\mathbf{B}$, or $\alpha$-neo-endorphin). Antiserum Brenda was used at a final dilution of $1: 40,000$. Camel $\beta \mathrm{E}_{1-31}$ was used in the standard curve, and [ $\left.{ }^{125} 1\right]$-labeled $\beta \mathrm{E}_{1-31}$ was used as the radiolabeled trace. 
Sensitivity of the assay under dysequilibrium conditions was approximately $2-3 \mathrm{fm} /$ tube, with an $\mathrm{IC}_{50}$ of approximately $20 \mathrm{fm}$.

$N$-acetyl $\beta$-endorphin RIA. Antiserum Nancy Beth (final dilution 1:8000) was specific for $N A c \beta E$. It fully recognizes $N A c \beta \mathrm{E}_{1-31}$, $N A c \beta E_{1-27}$, and $N A c \beta E_{1-26}$, and had less than $12 \%$ cross-reactivity with non-acetylated forms of $\beta \mathrm{E}$ (Dores et al. 1986). $N A c \beta \mathrm{E}_{1-31}$ was used as the standard, and [ $\left.{ }^{125} \mathrm{I}\right]$-labeled $N A c \beta \mathrm{E}_{1-27}$ was used as trace. Sensitivity of the assay was $6 \mathrm{fm} /$ tube, with an $\mathrm{IC}_{50}$ of $60 \mathrm{fm}$.

ACTH RIA. For this RIA, samples were resuspended in $0.1 \%$ human serum albumin (HSA) and run in ACTH buffer $(150 \mathrm{mM}$ sodium phosphate buffer with $1 \%$ polylysine, $1.6 \%$ normal rabbit serum, $0.7 \% \mathrm{NaCl}, 0.1 \%$ EDTA, $0.016 \% \mathrm{NaN}_{3}$, and $0.02 \%$ Triton $\mathrm{X}-100, \mathrm{pH}$ 7.6). Antiserum no. 21 , bleed 7 (final dilution $1: 80,000$ ), is spccific for the midportion of $\mathrm{ACTH}_{1-39}$. This antiserum cross-reacts with POMC, has $10 \%$ cross-reactivity with CLIP, but less than $0.1 \%$ molar cross-reactivity with $\alpha$-MSH (Dores et al. 1986). Sensitivity of the assay was $6 \mathrm{fm} /$ tube, with an $\mathrm{IC}_{50}$ of $50 \mathrm{fm}$.

$\alpha-M S H R L A$. This assay was performed under the same conditions as the $\beta \mathrm{E}$ assay. The $\alpha$-MSH antiserum was courtesy of Dr. Robert Dores (Denver, CO). It was used at a final dilution of $1: 30,000$ and requires amidation of the C-terminus for antigenic recognition (Young 1989). The sensitivity was $8 \mathrm{fm} /$ lube, with an $\mathrm{IC}_{50}$ value of $60 \mathrm{fm}$.

\section{Gel chromatography}

After aliquots were removed for assay of $\beta \mathrm{E}-\mathrm{IR}$, pooled extracts of post-lesion thoracic spinal cord segments were subjected to gel filtration chromatography to seperate $\beta E$-IR peptides on the basis of molecular weight. Chromatography was performed on a $1.5 \times 90 \mathrm{~cm}$ column with Sephadex G 50-50 fine gel and 1\% formic acid containing $0.01 \%$ BSA as the elution buffer. Blue dextran and cobalt chloride were used to mark the void volume and total volume, respectively. The column was precalibrated with $\beta \mathrm{E}_{1-31}$ and $\beta \mathrm{E}_{1-27}$ standards. Fractions of $1.4 \mathrm{ml}$ were collected with an automatic fraction collector. These fractions were dried down and subsequently assayed for $\beta E-I R$ as described.

\section{Statistics}

Data were analyzed by Student's $t$ test or ANOVA, with $P<0.05$ considered significant.

\section{Results}

In control animals, the total amount of $\beta E$-IR found in spinal cord regions agreed with other published results (Gianoulakis and Angelogianni 1989). The total amount of $\beta \mathrm{E}$ and $N A c \beta E$ ranged between 1.3 and $2.0 \mathrm{fm} / \mathrm{mg}$ tissue (Fig. 1). As can be seen in Table I, the proportion of $\beta \mathrm{E}$-IR that was acetylated appeared to rise as one progressed caudally in the spinal cord.

\section{TABLE I}

DEGREE OF ACETYLATION OF $\beta$ E-IR FORMS IN SPINAL CORD REGIONS

\begin{tabular}{ll}
\hline Region & $\% \beta$ E-IR acetylated \\
\hline Cervical & 35 \\
Thoracic & 46 \\
Lumbar & 53 \\
Sacral & 84 \\
\hline
\end{tabular}

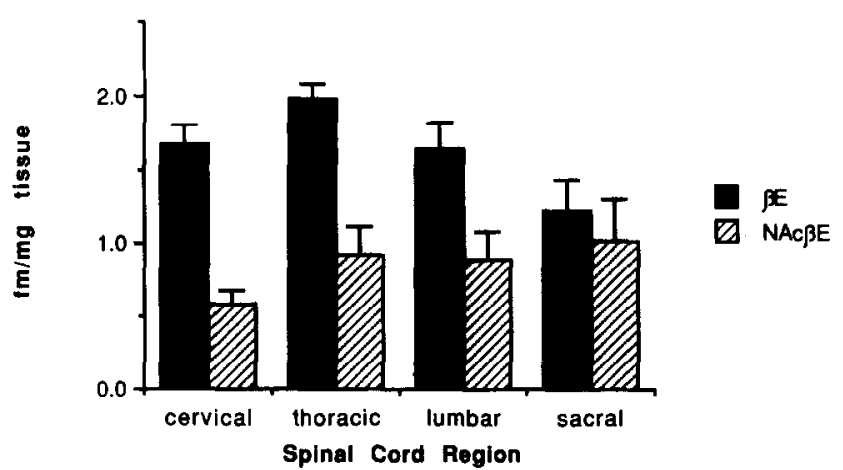

Fig. 1. $\beta$-Endorphin ( $\beta E$ ) and $N$-acetyl $\beta$-endorphin $(N A c \beta E)$ immunoreactivity in different spinal cord regions expressed as mean $\mathrm{fm} / \mathrm{mg}$ tissue \pm S.E.M. Assays performed as described in text.

The percentage of acetylation of $\beta E$ forms increased from $35 \%$ in the cervical region to $84 \%$ in the sacral region. Both $\alpha$-MSH-IR and ACTH-IR were detected in the cord, with combined values in the range of $0.6-1.2 \mathrm{fm} / \mathrm{mg}$ tissue (data not shown).

Molecular sieving performed on control thoracic spinal cords revealed a characteristic processing pattern, showing small concentrations of POMC, moderate amounts of $\beta$-LPH, and significant amounts of $\beta \mathrm{E}$, with a slight predominance of the opioid antagonist form $\beta \mathrm{E}_{1-27}$ over the agonist form $\beta \mathrm{E}_{1-31}$ (see Fig. 2).

Spinal cord lesions led to a substantial diminution of $\beta E-I R$ and ACTH-IR in the areas of the cord below the level of transection (see Fig. 3: $\beta \mathrm{E}, 67 \%$ decrease; ACTH, 57\% decrease). However, a significant amount of IR remained below the lesion after 3 days (Fig. 3). Attempts to concentrate the samples to increase the amounts of detectable $N A c \beta E$ and $\alpha$-MSH-IR caudal to the lesions resulted in non-specific tissue cffects interfering with the assay results. Bccause of these effects, we were unable to obtain reliable data for

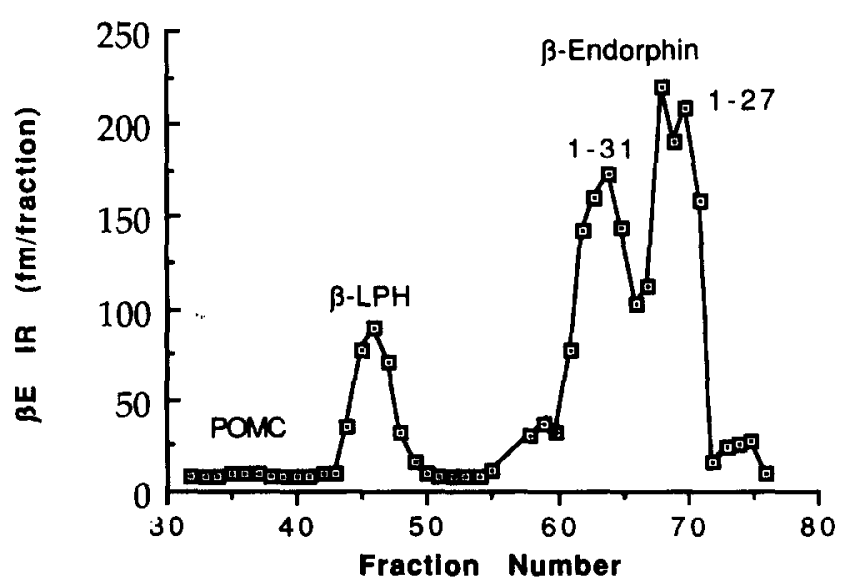

Fig. 2. Characteristic molecular sieving profile for thoracic spinal cord of control rats using Sephadex G 50-50 gel under conditions described in text. Relative elution positions of POMC, $\beta$-LPH, $\beta \mathrm{E}_{1-31} \beta \mathrm{E}_{1-27}$ are indicated. 


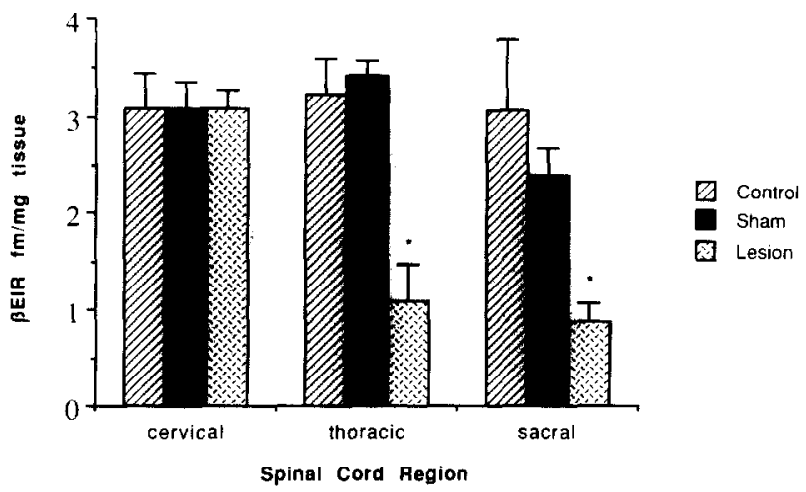

Fig. 3. $\beta$-Endorphin $(\beta E)$ immunoreactivity in control animals $(n=$ 5), after sham operation $(n=6)$, or 3 days after thoracic spinal cord lesion $(n=8)$. Values are expressed as mean \pm S.E.M. Spinal cords were divided into cervical (above the level of the lesion), thoracic, and lumbosacral (both below the level of the lesion) segments prior to assay. Data for animals 7 days after spinal cord lesion was similar to 3-day lesion animals, but the small sample size $(n=3)$ precluded inclusion in the graph. ${ }^{*} P<0.05$ from control and sham-operated animals.

these peptides. Another group of lesioned animals was killed 7 days after lesioning. Because of technical difficulties in keeping the animals alive, only 3 rats in this group survived to 7 days, rendering this sample too small to analyze in detail. Howcver, relative $\beta$ E-IR levels observed in all regions of the spinal cord of these 7-day lesion animals were not different from those observed in the 3-day lesion animals (see Table II), suggesting that even 7 days after lesioning, significant amounts of $\beta E$-IR persist in regions below the lesion.

In spinal lesioned animals, molecular sieving of the spinal cords below the level of the lesion revealed much higher relative amounts of POMC and $\beta$-LPH than of $\beta E$. While POMC accounted for less than $1 \%$ of the total $\beta E$-IR in control animals, it represented about $35 \%$ of the total IR in lcsioncd rats (sce Fig. 4 and Table III). The $\beta E$ peak in the post-lesion sieving profile revealed a preponderance of $\beta \mathrm{E}_{1-31}$ over

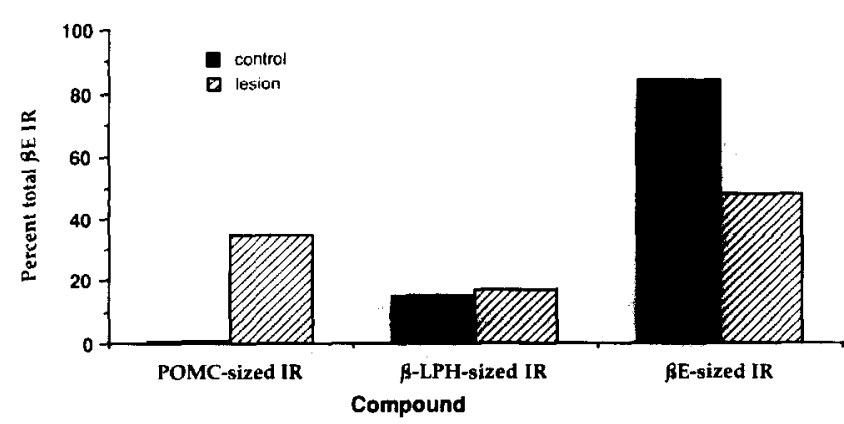

Fig. 4. Relative proportions of $\beta$-endorphin $(\beta E)$ to its precursor products in rat thoracic spinal cord before and after spinal cord lesioning. Amounts of each compound are expressed as a percent of total $\beta \mathrm{E}-\mathrm{IR}$.
TABLE II

RELATIVE RATIOS OF $\beta$ E-IR IN CERVICAL, THORACIC, AND SACRAL SPINAL CORD REGIONS

\begin{tabular}{llll}
\hline Group & \multicolumn{2}{l}{ Region } & \\
\cline { 2 - 4 } & Cervical & Thoracic & Sacral \\
\hline Control $(n=6)$ & 1.00 & $1.20 \pm 0.25$ & $1.00 \pm 0.24$ \\
Sham $(n=5)$ & 1.00 & $1.13 \pm 0.07$ & $0.80 \pm 0.09$ \\
3 day $(n=8)$ & 1.00 & $0.35 \pm 0.12 *$ & $0.29 \pm 0.07 * *$ \\
7 day $(n=3)$ & 1.00 & $0.38 \pm 0.11 *$ & $0.30 \pm 0.10 * *$
\end{tabular}

Ratios are \pm S.E.M. * Significantly different from control and sham animals at $P<0.05$. ** Significantly different from contrul animals at $P<0.05$.

\section{TABLE III}

RATIOS OF POMC: $\beta$-LPH: $\beta$ E AND $\beta \mathrm{E}_{1-31}: \beta \mathrm{E}_{1-27}$ IN CONTROL AND LESIONED THORACIC SPINAL CORDS

\begin{tabular}{lll}
\hline Treatment & POMC $: \beta-\mathrm{LPH}: \beta \mathrm{E}$ & $\beta \mathrm{E}_{1-31}: \beta \mathrm{E}_{\mathrm{t}-27}$ \\
\hline Control & $1: 24: 135$ & $0.75: 1$ \\
Lesion & $1: 0.5: 1.4$ & $2: 1$ \\
\hline
\end{tabular}

$\beta \mathrm{E}_{1-27}\left(\beta \mathrm{E}_{1-31}: \beta \mathrm{E}_{1-27}=2: 1\right)$, in contrast to control animals $\left(\beta \mathrm{E}_{1-31}: \beta \mathrm{E}_{1-27}=0.75: 1\right.$; see Table III).

\section{Discussion}

This set of studies was undertaken with 2 goals in mind: to examine the processing of POMC products in the cord and to begin to address the issue of the origin of this IR. While it was clear from our previous studies (Tsou et al. 1986) that some cord POMC material was of descending origin, the processing pattern seen in cord was discordant enough from brain patterns to suggest the hypothesis that other sources might exist. The presence of increased amounts of $\beta \mathrm{E}$ precursors (mainly $\beta$-LPH-sized-IR) observed in pilot studies was puzzling. If one assumed that all spinal $\beta E$-IR was derived from supraspinal sources, one would expect to see less precursor-sized IR than in rostral areas supplying the spinal cord, as peptide processing tends to increase with transport down the axon. Therefore, to attempt to investigate whether other sources might exist, we compared intact to spinally lesioned animals and looked at POMC content and processing in these animals. Our main conclusions are that (a) the spinal cord has a distinctive processing pattern not directly reflective of supraspinal inputs, and (b) this may be due to the possibility that the cord has an intrinsic POMC neuronal system, as a sizable proportion of $\beta E$-IR remains in cord up to several days post-lesion.

Our data suggest that the spinal cord has a POMCprocessing pattern that is unique in the CNS. The ratio of $\beta$ - LPH to $\beta \mathrm{E}$ in hypothalamus is about $1: 20$ 
(Gramsch et al. 1980; Emeson and Eipper 1986), and full size POMC is undetectable. In the caudal medulla, where $\beta$ E-producing cell bodies are also present, the ratio is 1:9 (Zakarian and Smyth 1982; Dores et al. 1986), again with no detectable POMC. In this study, we observed a $\beta-\mathrm{LPH}: \beta \mathrm{E}$ ratio of $1: 5$ in thoracic cord, with a small amount of POMC present (see Table III), although previous pilot studies performed in our laboratory did reveal slightly higher POMC concentrations. We have also observed that the proportion of $\beta$ E-sized-IR in the spinal cord that undergoes $\mathrm{C}$-terminal cleavage to shorter forms $\left(\beta \mathrm{E}_{1-27}\right)$ tends to increase as one progresses caudally (D.M. Bronstein, unpublished data). Giannoulakis et al. have made similar observations, finding a $\beta$-LPH : $\beta$ E ratio of $1: 3$ in cervical spinal cord, increasing to $1: 1$ in the thoracic, lumbar and sacral segments (Gianoulakis and Angelogianni 1989). In contrast, they report higher levels of the POMC precursor, with precursor : $\beta$-LPH ratios of $1: 3$ in cervical, $1: 2$ in thoracic, and $1: 1$ in lumbar and sacral cord. They also do not observe an increase in shorter $\beta E$ forms with caudal progression in the cord. It is unclear why our POMC: $\beta$-LPH and $\beta \mathrm{E}_{1-31}$ : $\beta E_{1-27}$ ratios differ somewhat from those obtained by Giannoulakis et al. Nevertheless, both studies agree that the $\beta \mathrm{E}$-processing pattern in the cord is distinctive and exhibits less post-translational cleavage than anywhere else in the CNS.

Overall, the $\beta E$-processing pattern observed in the cord seems most similar to that of the anterior piuitary (Zakarian and Smyth 1979; Gramsch et al. 1980; Young et al. in press). However, unlike the anterior pituitary, the degree of acetylation in the cord is significant. $\beta \mathrm{E}$ was $35 \%$ acetylated in the cervical cord, and this increased caudally to $84 \%$ in the sacral cord (see Fig. 1 and Table I). Acetylation of $\beta \mathrm{E}-\mathrm{IR}$ peptides is uncommon in the hypothalmi of both rats and humans (Gramsch et al. 1980; Emeson and Eipper 1986; Millington and Smith 1991) but is more prevalent in the caudal medulla (Zakarian and Smyth 1982; Dores et al. 1986). Since $\beta$ E-IR fibers project from the arcuate to the medulla (Palkovits and Eskay 1987; Palkovits et al. 1987; Sim and Joseph 1991), it could be postulated that the processing pattern seen in the spinal cord represents the true pattern of cellular processing in the NTS with progressively less contribution from arcuate projections in more caudal areas of the cord. Alternatively, it could represent a mixed pattern between descending and intrinsic sources of POMC. This notion was tested using spinal transection at the $T_{3}$ level.

Lesion data showed persistence of $\beta E$-IR for 3-7 days post-surgery. The most parsimonious hypothesis is that a certain proportion of the $\beta E$-IR in the cord (e.g., about one-third) derives from sources below the level of the lesion. However, alternative explanations for the anatomic origin of this IR could be proposed. For example, it could be postulated that this IR is simply retained within transected descending neuron terminals. However, our laboratory has shown, using immunocytochemical stains, that these descending neurons disappear by 3 days post-transection! (Tsou et al. 1986). It would stand to reason that peptides derived from these axons would be fully lost by that point or would continue to undergo degradation over time. Yet, at 7 days post-lesion, we did not see a detectable drop in $\beta \mathrm{E}$-IR concentrations relative to the 3 days post-lesion levels (see Table II). Furthermore, the processing pattern observed in the cord changed dramatically after lesioning. Thus, one would have to postulate both extensive retention of peptide in degenerating axons and selective degradation (or secretion) of specific POMC forms to support the hypothesis that all the IR is of supraspinal origin.

The alternative interpretation, based on the lesion and processing studies, is the existence, albeit limited, of a POMC system at the level of the cord. However, this hypothesis would not pinpoint the anatomic localization of this system within the cord. Two possibilities exist: the system could be present within the spinal cord per se or it could be due to expression of POMC products in dorsal root ganglion (DRG) cells. While $\beta E$-IR has not been detectcd in DRG cells, dynorphin IR has been identified by RIA (Basbaum et al. 1986), and it is conceivable that an analogous situation could exist for $\beta \mathrm{E}$. It should be noted, however, that neuronal $\beta E$-IR has been detected in the spinal cord by ICC during embryonic and early postnatal life (Haynes et al. 1982), disappearing by 1 month of age. This loss could be due either to an actual change in gene expression or to a dilution of the IR as cells grow and extend axons and terminals. Regardless, the early expression of $\beta \mathrm{E}$ in the cord leads us to favor the concept that POMC containing neurons could persist into adult life in amounts too low to be detected by ICC but detectable by our extremely sensitive RIA. Of course, this can only be proven if gene expression in specific spinal cells can be demonstrated. However, this is fraught with technical difficulties. To date, only sparse expression of POMC has been seen in cells of the NTS by in situ hybridization (Bronstein et. al., submitted). We are developing more sensitive anatomic techniques to help localize these cells.

Given the posibility of an intrinsic system, it was of interest to examine the nature of the IR following the removal of supraspinal input. The spinal cords of lesioned animals showed substantially less processing than anywhere in the CNS, with the unprocessed precursor representing at least one-third of the total IR (see Fig. 4 and Table III). It could be argued that these animals are clearly not normal, and their processing patterns could be altered from those which would exist 
in the intrinsic POMC neurons of an intact cord. Nevertheless, the pattern is so substantially different from that observed elsewhere (or in intact cord), that the alternative hypothesis needs to be given serious consideration, i.e., that intrinsic cells exist in the cord which exhibit relatively limited post-translational processing of POMC.

If we accept the idea of an intrinsic and a descending system contributing to the total POMC content of the cord, then the processing profile observed in the intact spinal cord should be a mixture of the patterns seen in the regions of origin. Combining supraspinal POMC-processing profiles with that observed in postlesion cord could yield the pattern seen in the spinal cords of intact rats. These profiles could represent differential expression of the PC1, PC2 (Benjannet et al. 1991), and $N$-acetylating (Glembotski 1982; O'Donohue 1983) POMC-processing enzymes in supraspinal and spinal cord regions. Thus, the various sources of POMC, through differential expression of these enzymes (e.g., less PC2 in cord), would have a different potential for post-translationally modifying the $\beta \mathrm{E} / \mathrm{ACTH}$ precursor.

It is interesting to note that the majority of the $\beta E-I R$ in the cord of transected rats is present in the highly opioid-active 31 amino acid form (see Table III). If this rcpresents the processing of the proposed intrinsic system, then perhaps this local system could play a role in pain processing at the spinal level. Intrinsic endorphinergic neurons could also be involved in the regulation of autonomic functions, as we (Lewis et al. 1987) and others (Hirsch et al. 1990) have suggested for the NTS.

In sum, we propose 3 conclusions from our study: (a) the POMC-processing pattern observed in the spinal cord of normal rats is unique in the CNS, combining limited processsing with a relatively high degree of acetylation, (b) one-third of the $\beta E$-IR content in the cord remains after spinal lesioning, and (c) the processing pattern of this remaining material is distinctive and is quite different from that in the intact animal. It also appears that the combination of supraspinal processing patterns and the pattern observed in post-lesion spinal cords could explain the pattern seen in the cord of intact animals. Taken as a whole, the available data lead us to favor the hypothesis that the $\beta E$-IR remaining after lesioning is of intrinsic spinal origin. The specific cells which might express the POMC gene remain to be described, and the exact roles of these 2 proposed subpopulations of $\beta E$ in the cord (intrinsic and descending) remain to be explored.

\section{Acknowledgements}

The authors would like to thank Dr. Tony Yaksh and Ms. Laura Breen for advice on the preparation and care of the spinal transected animals, and Mr. James Stewart for technical assistance. We would also like to thank Dr. Robert Dores for the $\alpha$-MSH antibody. Supported in part by NIDA Grant DA 02265 (to H.A.), a Medical Research Council of Canada Fellowship (to D.M.B.), and a Department of Anesthesiology Starter Grant (to H.B.G.)

\section{References}

Akil, H., On the role of endorphins in pain modulation. In: A Beckman (Ed.), The Neural Basis of Behavior, Spectrum Publ., Ann Arbor, MI, 1982, pp. 311-333.

Akil, H., Ueda, Y., Lin, H.L. and Watson, S.J., A sensitive coupled HPLC/RIA technique for separation of endorphins: multiple forms of $\beta$-endorphin in rat pituitary intermediate vs. anterior lobe, Neuropeptides, 1 (1981a) 429-446.

Akil, H., Young, E. and Watson, S.J., Upiate binding properties of naturally occurring $N$-and C-terminus modified beta-endorphins, Peptides, 2 (1981b) 289-292.

Akil, H., Watson, S.J., Young, E., Lewis, M.E., Khachaturian, H. and Walker, J.M., Endogenous opioids: biology and function, Annu. Rev. Ncurosci., 7 (1984) 223-255.

Akil, H., Young, E.A. and Watson, S.J., Pro-opiomelanocortin peptide secretion from anterior and intermediate lobe: effect of pre-translational and post-translation events. In: N.A. Thorn, M. Treiman and O.H. Petersen (Eds.), Molecular Mechanisms in Secretion, Alfred Berzon Symposium 25, Munksgaard, Copenhagen, 1988 , pp. 507-520.

Basbaum, A.I., Cruz, L. and Weber, E., Immunoreactive dynorphin $B$ in sacral primary afferent fibers of the cat, J. Neurosci., 6 (1986) 127-133.

Benjannet, S., Rondeau, N., Day, R., Chretien, M. and Seidah, N.G. $\mathrm{PC} 1$ and $\mathrm{PC} 2$ are proprotein convertases capable of cleaving proopiomelanocortin at distinct pairs of basic residues, Proc. Natl. Acad. Sci. USA, 88 (1991) 3564-3568.

Bradbury, A.F., Smyth, D.G., Snell, C.R., Birdsall, N.J.M. and Hulme, E.C., C fragment of lipotropin has a high affinity for brain opiate receptors, Nature, 260 (1976) 793-795.

Cahill, C.A., Matthews, J.D. and Akil, H., Human plasma $\beta$-endorphin-like peptides: a rapid, high recovery extraction technique and validation of radioimmunoassay, J. Clin. Endocrinol. Metab. 56 (1983) 992-997.

Chreticn, M., Scidah, N.G. and Dennis, M., Processing of precursor polyproteins in rat brain: regional differences in acetylation of POMC peptides. In: E.E. Muller and A.R. Genazzani (Eds.), Central and Peripheral Endorphins: Basic and Clinical Aspects, Raven Press, New York, 1984, pp. 27-33.

Cruz. L. and Basbaum, A.I., Multiple opioid peptides and the modulation of pain: immunohistochemical analysis of dynorphin and enkephalin in the trigeminal nucleus caudalis and spinal cord of the cat, J. Comp. Neurol., 240 (1985) 331-348.

Deakin, J.F., Dostrovsky, J.O. and Smyth, D.G., Influence of $N$ terminal acetylation and $\mathrm{C}$-terminal proteolysis on the analgesic activity of $\beta$-endorphin, Biochem. J., 189 (1980) 501-506.

Dores, R.M., Jain, M. and Akil, H., Characterization of the forms of $\beta$-endorphin and $\alpha$-MSH in the caudal medulla of the rat and guinea pig, Brain Res., 377 (1986) 251-260.

Emeson, R.B. and Eipper, B.A., Characterization of pro-ACTH/endorphin-derived peptides in rat hypothalamus, J. Neurosci., 6 (1986) 837-849.

Frederickson, R.C.A., Smithwick. E.L., Shuman, R. and Bemis, K.G., Metkephamid, a systemically active analog of methionine 
enkephalin with potent opioid $\delta$-receptor activity, Science, 211 (1981) 603-605.

Gianoulakis, C. and Angelogianni, P., Characterization of $\beta$-endrophin peptides in the spinal cord of the rat, Peptides, 10 (1989) 1049-1054.

Glembotski, C.C., Characterization of the peptide acetyltransferase activity in bovine and rat intermediate pituitaries responsible for the acetylation of $\beta$-endorphin and $\alpha$-melanotropin, J. Biol. Chem., 257 (1982) 10501-10509.

Gramsch, C., Kleber, G., Hollt, V., Pasi, A., Mehraein, P. and Herz, A., Pro-opiocortin fragments in human and rat brain: $\beta$-endorphin and $\alpha-\mathrm{MSH}$ are the predominant peptides, Brain Res., 192 (1980) 109-119.

Hammonds, R.G., Jr., Nicolas, P. and Li, C.H., $\beta$-endorphin ${ }_{1-27}$ is an antagonist of $\beta$-endorphin analgesia, Proc. Natl. Acad. Sci. USA, 81 (1984) 1389-1390.

Haynes, L.W., Smyth, D.G. and Zakarian, S., Immunocytochemical localization of $\boldsymbol{\beta}$-endorphin (lipotropin $\mathrm{C}$-fragment) in the developing rat spinal cord and hypothalamus, Brain Res., 232 (1982) 115-128.

Hirsch, M.D., Villavicencio, A.E., McKenzie, J.E. and Millington, W.R., C-terminal proteolysis modifies cardioregulation by $\beta$-endorphin, Soc. Neurosci. Abst., 16 (1990) 1025.

Holaday, J.W., Endogenous opioids and their receptors, Curr. Concepts, Upjohn, Kalamazoo, MI, 1985, 64 pp.

ladarola, M.J., Brady, L.S., Draisci, G. and Dubner, R., Enhancement of dynorphin gene expression in spinal cord following experimental inflammation: stimulus specificity, behavioral parameters and opioid receptor binding, Pain, 35 (1988a) 313-326.

Iadarola, M.J., Douglass, J., Civelli, O. and Naranjo, J.R., Differential activation of spinal cord dynorphin and enkephalin neurons during hyperalgesia: evidence using cDNA hybridization, Brain Res., 455 (1988b) 205-212.

Khachaturian, H., Lewis, M.E., Schafer, M.K.H. and Watson, S.J., Anatomy of the CNS opioid systems, Trends Neurosci., 8 (1985) 111-119.

Lewis, J.W., Baldright, G. and Akil, H., A possible interface between autonomic function and pain control: opioid analgesia and the nucleus tractus solitarius, Brain Res., 424 (1987) 65-70.

Millington, W.R. and Smith, D.L., The posttranslational processing of $\beta$-endorphin in human hypothalamus, J. Neurochem., 57 (1991) 775-781.

Nicolas, P., Hammonds, R.G., Jr. and Li, C.H., $\beta$-endorphin-induced analgesia is inhibited by synthetic analogs of $\beta$-endorphin, Proc. Natl. Acad. Sci. USA, 81 (1984) 3074-3077.
O'Donohue, T.L., Identification of endorphin acetyltransferase in rat brain and pituitary gland, J. Biol. Chem., 258 (1983) 2163-2167.

Palkovits, M. and Eskay, R.L., Distribution and possible origin of $\beta$-endorphin and ACTH in discrete brainstem nuclei of rats, Neuropeptides, 9 (1987) 123-137.

Palkovits, M., Mezey, E. and Eskay, R.L., Pro-opiomelanocortin-derived peptides (ACTH $/ \beta$-endorphin $/ \alpha$-MSH) in brainstem baroreceptor areas of the rat, Brain Res., 436 (1987) 323-328.

Sim, L.J. and Joseph, S.A., Arcuate nucleus projections to brainstem regions which modulate nociception, J. Chem. Neuroanat., 4 (1991) 97-109.

Smyth, D.G., Massey, D.E. and Zakarian, S., Endorphins are stored in biologically active and inactive forms: isolation of $\alpha$-N-acetyl peptides, Nature, 279 (1979) 252-254.

Tsou, K., Khachaturian, H., Akil, H. and Watson, S.J., Immunocytochemical localization of pro-opiomelanocortin-derived peptides in the adult rat spinal cord, Brain Res., 378 (1986) 28-35.

Tung, A.S. and Yaksh, T.L., In vivo evidence for multiple opiate receptors mediating analgesia in the rat spinal cord, Brain Res., 247 (1982) 75-83.

Walker, J.M., Moises, H.C., Coy, D.H., Baldrighi, G. and Akil, H., Nonopiate effects of dynorphin and des-tyr-dynorphin, Science, 218 (1982a) 1136-1138.

Walker, J.M., Moises, H.C., Coy, D.H., Young, E.A., Watson, S.J. and Akil, H., Dynorphin (1-17): lack of analgesia but evidence for non-opiate electrophysiological motor effects, Life Sci., 31 (1982b) 1821-1824.

Watson, S.J. and Akil, H., Immunocytochemistry of peptides. In: J.C. Barker and J.F. McKelvey (Eds.), Current Methods in Cellular Neurobiology, J. Wiley, New York, 1983, pp. 111-131.

Young, E., Adrenalectomy increases $\beta$-lipotropin secretion over $\beta$-endorphin secretion from anterior pituitary corticotrophs, Iife Sci., 45 (1989) 2233-2237.

Young, E., Bronstein, D. and Akil, H., Pro-opiomelanocortin (POMC) biosynthesis, processing and secretion: functional implications. In: A. Herz (Ed.), Handbook of Experimental Pharmacology, Springer, in press.

Zakarian, S. and Smyth, D., Distribution of active and inactive forms of endorphins in rat pituitary and brain, Proc. Natl. Acad. Sci. USA, 76 (1979) 5972-5976.

Zakarian, S. and Smyth, D.G., $\beta$-Endorphin is processed differently in specific regions of rat pituitary and brain, Nature, 296 (1982) 250-252.

Zimmermann, M., Ethical guidlines for investigations of experimental pain in conscious animals, Pain, 16 (1983) 109-110. 